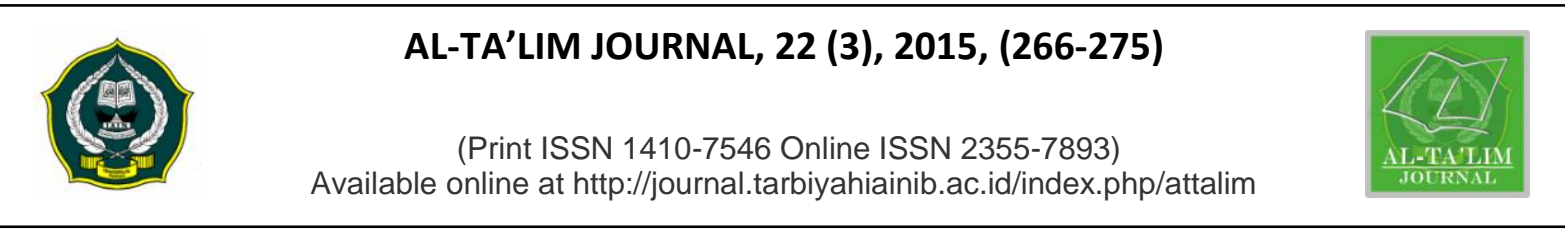

\title{
Brain Based Teaching Model as Transformation of Learning Paradigm in Higher Education
}

\author{
Zulfani Sesmiarni \\ Department of Islamic Studies, Faculty of Islamic Education and Teacher Training, \\ IAIN Bukittinggi, Indonesia \\ E-mail : zulfanisesmiarni@yahoo.co.id
}

Received: $13^{\text {th }}$ July 2015; Revised: $18^{\text {th }}$ Oktobery 2015; Accepted: $25^{\text {th }}$ November 2015

\begin{abstract}
Brain -based teaching model is a new paradigm that can facilitate students in optimizing student learning by the functioning the brain as a whole. Lessons are held today assume that all students equally so that learning provide the same services to each student in the class. With this model, the students are given different stimulation according to their abilities and needs. Base on brain learning theory -based teaching, the learning should pay attention to the five needs of the brain in general. The fifth factor is the need for a sense of comfort, the need for interaction, the need for knowledge, the need for the activity and the need for self-reflection. All these needs will be connected if the lecturers able to present emotional learning, social learning, cognitive learning, physical learning and teaching reflection.
\end{abstract}

Key Word : Instrucetional, Brain Based teaching, Learning

How to Cite: Sesmiarni, Z. (2015). Brain Based Teaching Model as Transformation of Learning Paradigm in Higher Education. Al-Ta Lim, 22(3). doi:http://dx.doi.org/10.15548/jt.v22i3.141

Permalink/DOI: http://dx.doi.org/10.15548/jt.v22i3.141

\section{INTRODUCTION}

Learning paradigm oriented in the intelligence development should refer to the function and performance of students' brain. Lecturer plays an important role in this case. This is explained by Jensen that the improving of brain chemistry can be stimulated by improving temper and perseverance in order to improve learning outcomes. Conducive classroom management is the urgent part in learning process

The reality of learning shows that learning process more concentrate on curriculum attainment targets than that raise students intelligent. As a result, students are given various kinds of information without being given the opportunity to conduct research paper and critical reflection, so that students are not able to give a positive response. This situation leads student to be passive.

Students are still as the object during learning process, the activity is limited in memorizing and receiving learning material. Students do the task and get punishment to their mistake. Lecturer rarely reward and praise for their achievement. Therefore, the effort to transform learning to empower the brain optimally is necessary to create learning orientating on empowering students' brain. Strategies related to how to 
implement brain-based teaching is to create an atmosphere or environment that enables to stimulate students' thinking ability. Teacher should provide fun learning environment and active learning atmosphere to the students. First, this way can be applied by creating an atmosphere or environment that can stimulate the thinking ability of students. This strategy can be done especially when the lecturer giving the questions to evaluate the subject. The questions provided should be packed effectively, so students' thinking ability can be optimalized through puzzles, simulations, games, etc

Second, teacher should endow with enjoyable learning environment, such as outdoor learning environment. Lecturers should avoid learning situations that can make students feel uncomfortable and boring. Learning strategies used emphasize more on group discussions that are interspersed with interesting games and other variations that would be able to create an excited learning atmosphere.

Third, creating an active learning atmosphere to the students, it can only be applied if the student able to do the physic and psychology activity optimally. Learning strategies used is packaged in such a way that students are involved in attractive and interactive, through demonstration learning model.

What proposed is a concerted effort in improving the quality of learning. But the key of success lies on lectures' motivation and ability to reform the method, learning strategies and lectures' enthusiasm to shift the thinking paradigm. So, it is more practical than theoretical.

To achieve this target, we need a brain-based teaching learning model that offers simple methods and relatively easy to understand and explain the ways that people like to learn and to develop. Learning used considers the learning structure with unite learning emotional, social, cognitive, physical and reflective. Thus, the students finally desire to learn, decide a vision to see what is possible. Students also motivate to develop their knowledge and skills. In addition, students are able to take action to transform the dream into reality. Then the student will examine their self-reflection and life motivation.

Based on this phenomenon, I interested to discuss brain-based teaching model as a new paradigm in optimizing the students' brain works.

\section{RESEARCH FINDINGS AND DISCUSSION}

Learning is a process of interaction in the learning process that consists of all components in the learning process in the classroom such as professors, students, materials, media, learning resources and environment. All components must be able to interact in order to achieve the purpose of the learning process.

Ward states that learning is a process that produces changes in mental capacity, motor skills, emotional well-being, motivation, social skills, attitudes, and cognition sustainable structure. Besides dealing with the interaction of learning in the classroom, then there is a relationship between students and professors that explained learning is influenced by confidence in the effectiveness of learning and also a lecturer in making connectedness. Social and emotional aspects of learning have an impact on the subject matter that has relevance for students.

Lecturers are expected to recognize and understand the function of the students' mind naturally so that the learning is effective. Learning should be started by creating a good emotional state, producing collaborative social condition, providing opportunities for students to think, facilitating students in learning activities and guiding the students to reflect their success. These processes require the knowledge and the development of brainbased teaching starting from the planning, 
implementation and evaluation. Jensen defines that brain-based teaching is an involvement strategy based on principles derived from one of brain perceptive. Brainbased teaching is a way of learning as the brain designed naturally. Brain-based teaching is also a way of thinking and considering how the brain learns optimally.

The opinions expressed above are the basic for the development of brain-based teaching model.

Barbara explains that the learning of brain-based teaching as described below: emotional learning, social learning, cognitive learning, physical learning and reflective learning.

\begin{tabular}{|c|c|c|}
\hline \multicolumn{3}{|c|}{$\begin{array}{l}\text { Tiga Teori Fungsi Kognitif: } \\
\text { Perbandingan Antara Sistem Otak, Kecerdasan Majemuk, dan Gaya Belajar }\end{array}$} \\
\hline $\begin{array}{c}\text { Sistem Pembelajaran } \\
\text { Alamiah Otak }\end{array}$ & $\begin{array}{l}\text { Kecerdasan Majemuk } \\
\text { Gardner }\end{array}$ & $\begin{array}{l}\text { Wilayah Gaya Belajar } \\
\text { Dunn \& Dunn }\end{array}$ \\
\hline Emosional & Intrapersonal & Emosional \\
\hline Sosial & Interpersonal & Sosial \\
\hline \multirow[t]{2}{*}{ Kognitif } & $\begin{array}{l}\text { Linguistik } \\
\text { Matematik } \\
\text { Musik }\end{array}$ & Psikologis \\
\hline & Visual/Spasial & \multirow[t]{2}{*}{ Fisik } \\
\hline Fisik & Jasmani/Kinestetik & \\
\hline Reflektif & Natural & Lingkungan \\
\hline \multicolumn{3}{|c|}{$\begin{array}{l}\text { Sumber: Data dari Gardner, H. (1983). Frames of Minds, New York, Basic Books, dan Dunn, R., \& Dunn, } \\
\text { (1993). Teaching Secondary Students through Their Individual Learning Styles, Boston: Allyn and Bacon }\end{array}$} \\
\hline
\end{tabular}

\section{Figure 1: Three Theories of Brain Function.}

Brain-based teaching is a learning designed to be adapted to how the brain works naturally. The basic concept is to synergize the functions of right hemisphere brain, the left hemisphere, learning styles, multiple intelligence, remembering (how to memorize), emotional brain, reducing stress and teacher expectations. Gagne also describes that a particular situation may motivate one individual because of prior learning, experience, or expectations

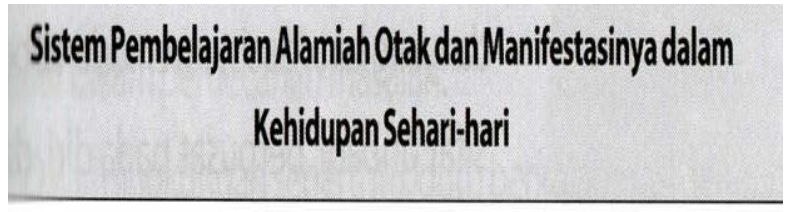

\section{Sistem Pembelajaran Alamiah Otak}

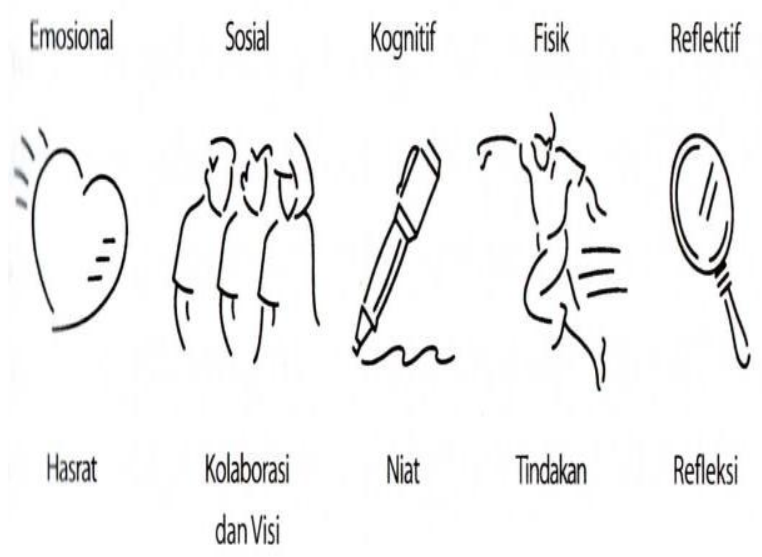

Figure 2: Natural learning System of Brain

First, emotional learning system of the brain is the prosecution system. This system should be comfortable before the thinking to be involved in cognitive learning. However, self-centeredness must not be allowed to dominate the individual. Emotional learning system should maintain a balance between emotion and selfishness. It also maintains the balance with all four other systems to gain comfort and wellbeing of themselves thoroughly.

Positive emotions emerge when lecturers and students feel comfortable about school. They will be responsible for learning activities, persevere until the task is completed, recognizing the standard of learning as a challenge and handle it with passion. By doing so, they create a harmonious social learning environment which intelligent learning can take place and feel free to express their personality.

In this case, Sprenger (2011) recommends that in developing intelligence and emotional strength, compassion is the key. In this case the lecturer as second parents in schools should spread 
compassion to every student, so emotional learning can be optimized. The learning of student will not effective if they are not provide a proper learning atmosphere

Lecturers who cultivate emotional system serve as a mentor for students to demonstrate a genuine enthusiasm to the students; by helping students discover a passion for learning. By guiding students can realize personal goals that are reasonable by supporting them in attempting to be anything they can accomplish. Thus, learning needs to be interesting, challenging, and relevant to the students and be able to be achieved or be in the zone of proximal development. Students can finish the task independently with such capabilities assisted by lecturers, peers or parents. If the study meets all of these criteria, academically, students will be ready to learn

Second, social learning includes the brain social learning systems that need affiliation and expect to be respected and recognized by all group members. This system is struggling to gain the praise of others that are considered important and enjoy while learning-related with those who have similar thoughts. To be part of the group is the greatest need of this system. If social learning supports individual, confidence will appear.

A stability social system allows the relationship with people of various ages develops properly. All students, especially those who have limited proficiency in social learning, require a lecture as collaborators in developing their social skills such as interactive learning to solve problems with teachers and other peers.

The natural tendency of social learning system is the desire to be part of the group to be respected, and to enjoy the attention of others. If the emotional system is personal, self-centered and internal, the social system focuses on interaction or interpersonal experience.
Students' social needs forced the lecturers to manage schools into learner community where lectures and students work together to determine the decisions and to solve real problems. In students' community, lecturers and students interact as a family. Students received awards and attention for their advantages. By focusing on the student advantages in classroom context, lecturers received a distinction as an individual blessing to be respected. This method maximizes social development through sincere cooperation between individuals. The divergences between them are creating creative an adventure in problem solving.

In such environment, teachers and students collaborate as equal partners in solving the problem. The lecturers associate verbal communication skill to support social learning and collaborate with students to review the knowledge and procedures that have been studied and teacher created new possibilities for all community members.

\section{Collaborator Lecturer creates} learning opportunities that are relevant to the tasks and projects that student interest in. This is because lecturers connect new learning with what students need. Collaborators goal is to build a learning community that provides respect, responsibility and relationship feelings, lovely relationship for all its members.

Third, cognitive learning system is a processing information system in the brain. This system absorbs and interprets outside information and all other systems. It guides the problem-solving and decision-making. Principal task of cognitive system is to assess the emotional sensations and social situation so it then takes action based on that assessment.

Cognitive system discussion puts a lecturer as learning facilitator and students as the one who solve problem and make decision. A facilitator sets the stage of learning. A facilitator does not provide the answers, but he presents the problem to the 
class to be solved and prepares supporting materials for solutions.

The purpose of cognitive learning systems of the brain in individuals is to develop new knowledge and skills. The system is also deliberately planned and prepared to realize the desire of emotional learning and vision systems resulting from the interaction of cultures.

Lecturers can stimulate and facilitate students' learning by addressing the need in order to find various methods. They must facilitate learning by giving lessons to optimize every natural learning system. By providing various methods through the different systems, students are free to obtain new information. Providing options to students' tasks can improve the students learning activities.

Fourth, brain's physical learning system involves a process of interaction with the environment to develop new knowledge and skills, or to express a variety of emotions and concepts. Using physical learning system to learn new information, comprehend difficult concepts. Developing new skills is as important as showing what has been learned by imitating and creative expression.

Learning is also depend on the physical learning system needs to do a lot of things and the students' tendency to be actively involved in learning. Although some students avoid tactual learning (active participation) and kinesthetic (movement or action oriented), other students can enjoy learning only if this modality involved. Physical learning system including challenging academic tasks is similar to sports; lecturers train, inspire, and encourage the active participation to achieve success. Physical learning system needs to be actively involved, because this system cannot process the information passively and then represented into the exam.

In the classroom, students who have a strong enthusiasm to be active usually get the anxiety of manipulative materials used. Even students who are physically active enjoy the learning process, create their own learning materials, and alter the information to be learned into an interesting story, make a poster or other products.

The brain's physical learning system transforms passion, vision and intentions into action, because this system is driven by the need to do something. Physical systems require movement, activity, and practical and structural learning accommodated by neural network.

Fifth, Reflective learning is a system that monitors and regulates the activity of all other brain systems. Reflective learning system has a particular need to test the student. Lecturers who guided students' exploration help students reflect their emotions, interactions, thoughts, ideas and behavior of the past, and links it with what is happening today.

Reflective learning system requires students to understand themselves. It can be developed through a trial. For example, recording of achievement and interpretation of student progress could be an evaluation of system and subsystems of learning for a certain child. Sprenger (2011) explains that the reflection process can be influenced by the style of learning, emotional level or specific content.

Brain-based teaching leads all activities to the principles of neuroscience and strategies or methods used with a certain purpose. It is described by Jensen that brain-based teaching is best known for its engagement, strategies and principles.

Brain-based teaching is an involvement strategy based on principles derived from the brain understanding. It is also a way of learning in accordance with a scientifically brain designed to learn. These principles must be recognized in realizing the brain-based teaching into learning process; Ronis (2007) describes the 12 principles of brain-based teaching: 1) the brain is a living system, 2) the brain is a 
social brain, 3) meaning recognizing is the first step, 4) meaning searching occurs through the formulation of pattern, 5) emotions determine the success of pattern formulation, 6 ) each brain simultaneously feel and create the whole parts, 7) the learning involves focused attention and additional perception, 8) Learning always involves emotional and unemotional process, 9) human being has two types of memory, 10) evolved learning, 11) complex learning can be upgraded by the challenges and slowed by threat, and 12) every brain set uniquely.

In brain-based teaching lecture role changed from conventional learning. Lecturers are required to facilitate the creation of knowledge and understanding. Learning should be organized as a foundation for students to develop new skills and overcome new challenges.

A few practical rules proposed by Ward including : a) How to motivate students, b) development of students 'skills in the field of research, c) The importance of students physical activity to encourage learning, d) Improving students' skills in the areas of language and comprehension of scientific vocabulary, e) direction for students of various ways of science recording, f) effective strategies to assess science learning, g) ideas to support creativity, h) the importance of using technology to support and encourage learning

Some lecturer roles in brain-based teaching are: first, as a role model and mentor, as collaborator, as facilitator, as trainer/coach and the last is as observer and supervisor. In this learning model, the system is related and associated with emotions, relationships, cognition, sensory and self-assessment in the learning environment. Emotional learning system determines the desires, dreams and personal desires. This system stimulates the spirit, attitude and creativity, raises a sense of self empowered and energized, or depresses and paralyzes all other systems.
Social learning system can be applied trough social system governing the self interaction and communication with others. This system controls the language developed, solves the problems through collaboration and respect individual differences. This system is struggling to gain acceptance, love and a sense of belonging.

Cognitive learning system Interprets, stores and displays information; deliberately focuses on information providing input to all other systems. This system best works when a person feels safe and protected. Physical learning system gathers information through the sense and is distributed throughout the brain and body. This system is responsible for changing the input from the senses and internal systems into action and best works if the environment let someone control the action and self progress.

Reflection learning system considers thoughts and past experience; present and future, then predicts future outcomes by asking a number of questions to our self. This system plays an important role in society and how they build a life. This learning enables to overcome students' general conditions such as fear, anxiety, boredom, apathy, frustration and confusion.

These conditions will greatly affect the learning process that occurs to raise the progress. This situation continuously transforms to students' dreams condition. This condition allows student to have a sense of anticipation, convincing them, curious, motivated, and open-minded. The condition expected will be able to attain learning goals. In this case, lecturer takes a big part in maintaining classroom environment. Student progress is depending on how teacher facilitates student in learning activity. The more creative and innovative a teacher, the better progress students have.

Some important aspects that can be considered by lecturer in empowering students in the classroom are important to 
understand that at the beginning of the learning activity, students had various conceptions, knowledge relevant to what they learn. Students' knowledge and understanding will be very useful to help students learning activity. Students will be helped to improve their wrong conception, incomplete or even to enhance the knowledge they already possess.

The goal of this emotional learning is to guide the student to meet their self needs. In addition this study aims to empower themselves, to develop the desire to achieve students' personal goals. The role of lecturers should be able to stimulate the desire of the students themselves.

The role of lecture in this learning model is as a stimulator directing enjoyable learning process, Lecturers appearance and interaction skills greatly affect the desire of students to learn. So, lecturers are required to develop learning design attractively.

In its application, lecturer begins by conditioning the students in a comfortable situation. Lecturers guide students to pray, reading the verse of Al-Quran, by affirmation and praise, by singing, games and other interesting things. This will stimulate students' brain in comfort zone and ready to study.

Student requires a professional lecture in order to create long-term comfort. This situation must be support by lecturers' ability in maintaining learning environment. Lecturer also supposes to recognize student need both in generally and personally.

If at the beginning of learning has been guided. It will raise a sense of fun. This feeling will encourage the brain to stimulate the amygdale to react. So, the neurons will be connected to stimulate into social learning. Social nature of the brain, which allows enhancing learning in a group situation, will respond the stimulation to other learning activities. This is the learning of theater contained in the brain which is the emotional, social, cognitive, and physical and reflection.
Emotions accelerate the thinking ability of students by providing direct physical responses to the surrounding environment. When a student being in comfort zone. His brain will proceed optimally in learning. Students' balanced emotion will affect the succeed of learning.

The second Theatre of brain's natural work is social learning. In its learning process, students always interact with their social groups, both students with peers and lecturers or learning resources. Student is unable to understand the learning without any social interaction with others. Social learning goal is to convince students how to be a member of a group. This social learning can be obtained through collaboration, lecturer interaction and environment to develop a clear vision of goals

The role of lecturer in social learning is as collaborative partner. It goals is to present students' vision and goals through team work or collaboration with his environment. Student skills will increasingly develop their learning experience while being in the social environment. Lecturers can create a social learning system by building close relationship among students. By doing so, student will have positive relationship to support student learning progress

In the social learning, lecturer should be able to give instructions and guidance to students in various educated methods. The brain will stimulate properly through emotional and social involvement. In this case, student will be able to learn and capture information with emotional learning quietly and pleasantly.

Atmosphere of collaboration in social interaction in the classroom need to be supervised incessantly by lecturers to stimulate students involvement in learning. Learning is characterized by the interaction between all components in the learning. Without the empowerment of each component it turns the learning to be 
monotonous. Thus, social atmosphere guarantees learning objective.

The third Theatre of natural brain works is cognitive learning. Question session is the main and essential part of learning. It trains the student to convey ideas and to provide relevant responses to a problem raised. Questioning is a key feature of classroom learning. A wide range of questions will widen student knowledge.

The goal of cognitive learning in neuroscience is a new science discussing the relationship between neurons activities and cognitive behavior. Brain working based is able to overcome the students problem during the study. From the perspective of brain working based learning, the most effective way to teach thinking skills is to combine real-world problems and authentic conditions.

Cognitive learning aims to find out lecturers' role in learning process, this learning refers to an intellectual response. The most important task of the brain is to think and solve problems. Learning is an interactive process that occurs on many levels. Learning should be started by searching, filter, merge, process, evaluate and store the information to be used then.

The desire of students' better understanding is supported by various methods presented by lecturers. It is facilitated by the opportunity to explore either visually or audio. Cognitive learning is able to instill the concept it to the natural system of the brain.

Fourth, Physical Education, student activities through various concrete activities with nature becomes the main point in learning. This activity can be done in the classroom with the tools and learning resources. With a variety of real activity, the students will be confronted with the phenomenon to be studied, thus these activities allows a process of active learning.

Physical learning is an important principle in the learning interaction. This is because the learning is done to change behavior through activities. Student activities are all activities during the learning process. These activities include hearing and enthusiasms on lectures' explanation, reading or understanding the contextual books, solving problems or finding answers to the contextual problem, expressing opinions, discussing and asking question among friends.

Physical learning goal is to satisfy the need. The lecturers' role in this study is as a coach, trainer because teachers should develop students' psychomotor. Lecturer should create active learning by taking action to achieve the learning objectives, such as listening and writing. Learning activities is a motoric activity that conducting experiments, so all the learning activities integrated into the activities.

The physical performance will trigger the brain to strengthen memory and improve connections between nerves if the students do a lot of activities. Physical movement is a different way of learning by providing motivation. Physical activity will be able to overcome students' low motivation. Physical movement in learning can be done in various ways such as experiments, games and a various relevant methods.

Fifth, reflective learning, the fundamental aspect of Learning is students' awareness of their ability. Students' curiosity to explore a variety of new knowledge, and eventually can apply it in their lives. This course is supported by the developments and the growing of students' curiosity, students' methods to assess the information, make decisions and seek a range of applications that are appropriate to be applied in society.

Reflection activity is the students' activity of presenting and explaining the benefits of topic learned. This activity can also be applied by explaining what things are not controlled or interesting parts of material learned. 
The brain records the surrounding information, both conscious and unconscious level. For that, the class should be well-designed so it enables to stimulate the brains' activities. Class room design such as color, image, natural lighting is the best for learning. In addition, it is necessary to create a state of the environment by light setting; seating or temperature, sound, plants and comfort environment.

Brain working Based learning involves the student into learning activity. Student is raised as the object of learning. Physical and mental involvement will stimulate student learning activity in order to attain the significant progress.

Thus, brain working based learning is effective to be applied in College. These findings can be used as reference of natural brain working based learning. It will increase learning progress through planning, implementation and evaluation which is designed in multisensory methods.

In addition, it is necessary to provide variation of stimulation for students through various learning methods. Subsequently, students must be lead to the active activity by doing presentations and others using their interest. In this case, lecturer acts as facilitator, coach, manager and supervisor to provide an optimal learning. In addition to the lecturers' physical learning is also able to determine the responsibility of a coach, leader and mentor.

Students facilitated with comfortable situation, peaceful and emotionally happy will stimulate their learning motivation. This situation will enhance the sense of social environment interaction. This will provide a wide connection of knowledge to be established, so that children are able to master the concepts. Furthermore, the lecturer able to train student activities through a variety of learning activities that involves them. Finally the students are able to make sense of any learning activity by reflection and contemplation.
This learning method will provide the solution to students' general problem such as fairness, anxiety, boredom, apathy, frustration and confusion. These conditions will greatly affect the learning process and the progress obtained.

This situation can be greatly changed to the desirable condition through this method. So the goal of whole learning activity is completely established. To achieve this goal, the role of the lecturer will be very influential in conditioning classes. This is because the lecture is a learning model during learning. The more varieties teacher designs a learning process, the better students obtain the progress.

\section{CONCLUSION}

The learning of brain-based teaching is learning process that intends to optimize the workings of the brain in capturing new information. Brain works learning model supposes the lecturers to be able to facilitate students to maximize student brain capability.

This capability consists of emotional learning, social, cognitive, and physical and reflection. This learning model strongly emphasizes the role of emotion in learning. Emotions will stimulate students' thinking. Learning should respect the emotions, feelings, beliefs, needs, problems, attitudes and skills possessed by students.

\section{REFERENCES}

Given, BK. (2007). Brain Based Teaching , Bandung: Kaifa Press

-----. (2002). Teaching to the Brain's Natural Learning System, Alexandria: ASCD.

Rohis, D. (2011). Asesmen sesuai cara kerja otak, Jakarta: Indek Press

Jensen, E. (2009). Super Teaching, California ; A SAGE Company

-----. (2011). Pemelajar Berbasis Otak, 
Jakarta : Indek Press.

-----. (2008). Brain Based Learning, Corwin Press: A SAGE Company.

Gredler, M. (2009). Learning and Instruction Theory into Practice. New Jersey: Pearson.

Ward, H. (2007). Using Their Brains in Science, London : A SEGE Publication Company.

(2010). Pengajaran Sains Berdasarkan Cara Kerja Otak, Jakarta; Indeks.
Sperenger, M. (2011). Cara Mengajar Agar Mahasiswa Tetap Ingat, Jakarta: Erlangga.

Rohis, D. (2007). Brain Compatible Assessments. California: Corwin Press.

Robert M. Gagne, Walter W. Wager, etc, (2005). Prinsiples of instructional design, fifth edition, Wadworrh: Thomson.

Buzan, T. (2005). Brain Child Cara Pintar Membuat Anak Jadi Pintar, Jakarta: Gramedia Pustaka Utama. 